Published online May 2016

\title{
Informers, agents and the liberal ideology of collusion in
}

Northern Ireland

\section{Professor Mark McGovern}

\section{Professor in Sociology}

Department of Social Sciences, Edge Hill University, St Helens Road

Ormskirk

Lancs L39 4QP

Tel: 01695584621 (W)

07970002085 (M)

E-mail: mark.mcgovern@edgehill.ac.uk

Word Count: 10,480

\section{Acknowledgements}

I would like to acknowledge the help and support of Relatives for Justice and their families. A special thanks to Mark Thompson, Director of RFJ. This work was supported by the European Union under the Peace IV Special Programme for Peace and Reconciliation Fund, via the Harms to Rights strand of the Relatives for Justice 'Transitional Legacies' programme and by the British Academy under the Small Grants Award Scheme. 


\title{
Informers, Agents and the Liberal Ideology of Collusion in Northern Ireland
}

\begin{abstract}
There is now considerable evidence of systemic and institutionalised collusion between state forces and loyalists paramilitary groups during the Northern Ireland conflict, not least in the late 1980s and early 1990s. Focussing on a critical reading of the 2012 de Silva report into the killing of human rights lawyer Pat Finucane, this article examines state collusive practices surrounding the handling of agents and informers as evidence of a culture of collusion extending into the highest echelons of state institutions. The article will argue such practices evidence an approach to state counterinsurgency predicated on a 'doctrine of necessity' and what will be understood as a 'liberal ideology of collusion'.
\end{abstract}

Keywords: Counterinsurgency, Collusion, Extra-Judicial Killing, Pat Finucane, State Violence, Northern Ireland

An unfortunate attitude... then persisted within RUC Special Branch and the Force Research Unit. Namely, that they were not bound by the law and were above and beyond its reach [my italics]. (Cory 2004, 96)

\section{Introduction}

There is now a considerable body of evidence pointing to widespread, systemic and institutionalised collusion involving the British army, the Royal Ulster Constabulary (RUC) and the Ulster Defence Regiment (UDR) with loyalist paramilitary violence and killings in Northern Ireland throughout three decades of conflict (Cadwallader 2013, Cory 2004, de Silva 2012, Larkin 2004, MacAirt 2012, PFC 2014, Relatives for Justice 2012, 2012a, Stevens 2003).' Much of what we now know has only come to light in recent years as the result of ongoing truth and justice campaigns. Only in 2012 did the publication of an official report by Desmond de Silva QC into state collusion in the 1989 loyalist killing of human rights lawyer Pat Finucane in his Belfast home lead to a public apology issued by British Prime Minister 
David Cameron (McDonald and Bowcott 2012). The evidence of the extent and nature of collusion revealed in the de Silva report was startling. Not least, for example, that over $85 \%$ of the intelligence held by loyalists and used to organise their escalating campaign of killings in the late 1980s was derived from state intelligence files (de Silva 2012, 252-60). Yet, the meaning and significance of collusion in this and many other cases remains deeply contested and de Silva's own limited conclusions worthy of critical reflection.

The aim of this article is to examine what will be called the 'liberal ideology of collusion' as an aspect of British state counterinsurgency practice in Northern Ireland (Luban 2014). Based primarily on a critical reading of the report of the de Silva review the argument will focus on the role of agents and informers within loyalist paramilitary organisations and their relationship to collusion and British counterinsurgency strategy in the North during the late 1980s and early 1990s. However imperfect (and intentionally or not) the de Silva report provides important insights into the mind-set, the institutionalised ethos, culture and outlook that prevailed within the highest reaches of the state. As such, a critical reading of de Silva can provide a means to evaluate the nature of what was taking place. It is that reading of what de Silva says, some of what he does not say, and some of the problems that emerge with his interpretations of what was said and done, that therefore form the core focus of this analysis.

The article will be divided into four parts. First, the changing character of state counterinsurgency in the North will be outlined before examining developments in the 1980s and 1990s that highlight the ever greater emphasis placed on the use of agents and informers and the 'primacy of counterinsurgency' in policing (see also McGovern 2015, $2013,2011)$. The article will then go on to look at two particular aspects of collusion as evidenced in the de Silva report. First, is the nature of agent and informer activity in terms of 'leaks' (or the provision of state-sourced intelligence) and weapons to loyalist paramilitaries. Second, the rules governing the handling of agents and informers then in place or (to be more exact) the lack of such rules and how de Silva interprets this absence. Finally the article will critically reflect on the wider meaning of what is understood as a deeply embedded culture and pervasive 'liberal ideology' of collusion (Luban 2014) as a paradigm of contemporary governance (Agamben 2005) and counterinsurgency practice. 
Collusion here is understood as the involvement of state agents (members of the police, army, prison and intelligence services) or state officials (government ministers, legal officers, civil servants), directly or indirectly, through commission, omission, collaboration or connivance, with armed non-state groups or agents, in wrongful acts involving, or related to, non-state political violence (McGovern 2015). Rather than the outcome of individual intentions and actions collusion is also understood as historically and structurally shaped and framed. It occurs within specific institutional settings (such as the British military) with their own hierarchical orders, normative and ideological cultures, instrumental logic, policies and practices. Institutional collusion involves patterns of wrongful acts or omissions that 'overtly or covertly reside in the policies, procedures or operations and culture of public or private institutions', forming a set of practices 'inhered in the apparatus of the state and the structures of society' (Bourne 2001; Sivanandan 2008).

\section{Counterinsurgency and the North}

Often celebrated as what 'fundamentally defeated the IRA' the use of informers and agents is widely recognised as an ever more important cornerstone of British state counterinsurgency strategies in the North from the early 1980s onwards (Kirk-Smith \& Dingley 2009, 51, Moran 2010). Yet, while mainstream academic analysis of British counterinsurgency 'success' acknowledges this could involve 'overt collaboration in murder' and came at the price of the police employing 'highly dubious methods' (Bamford 2005) raising 'major ethical questions' there has still been an insistence such an approach fell far short of 'a concerted state policy to use informants to commit murder' (Moran 2010, 20-21). This, of course, is precisely what needs to be critically assessed. However, it might first be worth considering how and why the emphasis on the role of agents and informers emerged in the broader context of the developing state approach to counterinsurgency in Northern Ireland.

For Adrian Guelke (2007) shifts in British counterinsurgency policy formed three distinct phases. An initial 'militarisation' phase (late-1960s to mid-1970s) gave way to 
'criminalisation' from the mid-1970s to the early 1990s, followed by an 'accommodation' phase with the onset of the peace process and after. The 'war model' (Campbell \& Connolly 2003) of the early 1970s, saw a high number of state killings, particularly of Catholic/nationalist civilians (Ní Aoláin, 2000). This presented the state with a number of problems, not least because such repression proved counter-productive, feeding a rapid and devastating escalation of violence and generating rather than dissipating levels of resistance to the state itself. The 'war model' also involved employing counterinsurgency strategies and repressive force used in other colonial campaigns creating a profound paradox for the British state. Such an approach underscored the view of those (not least the state's principle enemy, the IRA) who argued the North was indeed Britain's 'last colony' even as Government rhetoric specifically sought to deny it. In essence, the problem therefore became one of how to conduct a counterinsurgency campaign capable of achieving the state's military goals while maintaining and advancing its political and ideological ends; not least in preserving the self-projected legitimacy of the state by arguing that liberal democratic norms, values and practices were being upheld. This was critical in shaping the emerging state strategy of 'criminalisation', 'normalisation' and 'containment' (O'Dowd, Rolston and Tomlinson 1982, Rolston 1991). The ideological battle would be fought on the terrain of 'criminalising' and de-politicising opposition to the state (leading directly to the prison protests and ultimately the 1981 republican hunger strike) while the use of force was increasingly calibrated by this overarching political logic.

Typologies of state counterinsurgency campaigns are often more distinct in theory than in practice. As Guelke $(2007,275)$ himself notes, in reality the phases he identifies were far from being 'watertight compartments'. In the midst of 'militarisation', for example, the state (or elements within it) could still favour and pursue alternative, political approaches, as evidenced by the 1972 Conservative Government talks with republicans and the failed Sunningdale power-sharing agreement of 1974 (Bew and Patterson 1985, Cunningham 2001, Smith 2011). Similarly, during the prolonged (if often breached) IRA ceasefire of 1975 a Labour Government, likely giving serious consideration to a 'withdrawal' option, held protracted secret talks with the republican leadership (Ó Dochartaigh 2011). However (and in no small part because of the often simultaneous contradictory and countervailing use of coercive and lethal state force, exemplified in the Bloody Sunday massacre of January 1972) 
all such efforts ultimately failed, auguring in the containment strategy that followed (O’Dowd, Rolston and Tomlinson 1982, Rolston 1991, Walsh 2000).

Similarly, as Guelke $(2007,276)$ argues, while 'proclaiming a stance of criminalisation, a government may covertly pursue policies that are consistent with suppression, such as a policy of targeted assassinations or a "shoot-to-kill" policy". We might go further and argue that far from being in any way mutually exclusive, 'criminalisation' and covert 'targeted assassinations' were intrinsically tied to one another. Such a perspective informs the analysis of Ní Aoláin $(2000,29-71)$ who like Guelke proposes a three part typology of the phases of the conflict but emphasises the close inter-relationship of legal and political strategies and the state's use of lethal force. For Ní Aoláin $(2000,57)$ the ending of 'militarization' in 1974 though followed by a 'normalization' phase was superseded from 1981 to 1994 by 'the alliance of active counterinsurgency and extraordinary law'. This analysis highlights the importance of distinct developments in counterinsurgency practice emerging at the start of the 1980s. The wake of the 1981 Hunger Strikes, Ní Aoláin $(200,58$, 66) suggests, witnessed a 're-established [and] more systematic... active counterinsurgency', exemplified in the strategic deployment of specialist units of the British military (the SAS) in a 'shoot-to-kill' policy focussed on a series of set-piece ambushes of republican combatants in specific geographical areas (Hearty 2014). This use of 'massive and deadly firepower' combined with the further adaptation of emergency laws, the subverting of legal due process and the militarisation of the RUC. This is an important context to understand the particular nature of collusion and its relationship to the rise of the use of informers and agents in the same period.

That said, collusion was evident long before the 1980s. Links between loyalist paramilitary groups and locally-recruited state security forces pre-dates the outbreak of the conflict; indeed go back to the foundation of the state itself (Farrell 1983). From the 1970s onwards, exemplified in the activities of the 'Glennane Gang' (an Ulster Volunteer Force [UVF] unit responsible for dozens of sectarian killings of Catholics in the murder triangle of South Armagh and East Tyrone) the ranks of the RUC and (even more) the Ulster Defence Regiment (UDR) contained many who were also active in loyalist paramilitary groups (Cadwallader 2013, Pat Finucane Centre 2014). There is considerable evidence of high 
ranking tacit support or worse for such activities (Cassels et al. 2006). At the same time, 'counter' or 'pseudo-gangs' ('undercover' or 'locally recruited' units who would operate as covert forces to combat insurgent groups) were organised and run by British military intelligence from the earliest days of the troubles and psychological operations and black propaganda were part and parcel of counterinsurgency strategies (BBC 2013, MacAirt 2012, Newsinger 2002, Rolston 2006).

However, from the early 1980 s onward the resort to 'active counterinsurgency' combined with the attempt to maintain the fiction of 'constitutional normalcy' only placed an evergreater emphasis on the intelligence war. This was the specific environment that framed the form collusion would take in the late 1980s and early 1990s. The adoption of an overarching counterinsurgency strategy (exemplified in the 'shoot-to-kill' policy) constituted a campaign of attrition mounted on a range of fronts - social, political, informational, legal and military aimed at isolating, demoralising and destroying the 'will to resist' of a broadly defined republican 'enemy'. In turn, this required the creation of a model of policing based on the primacy of counterinsurgency and covert operations in which other aspects of policing were subverted to the end of tackling insurgent groups and placed a premium on the recruitment, use and protection of agents and informers.

\section{Informers, Policing and Collusion: Counterinsurgency, the RUC and the Walker Report}

Substantial structural and procedural changes for the handling of agents and informers within the RUC from the early 1980s onwards signalled such 'human assets' were being seen as central to counterinsurgency efforts. As Paddy Hillyard $(2013,2)$ has argued, the centralising of agent handling and intelligence and the promotion of Special Branch as a 'force within a force' undermined the core legal basis of policing concerned with the 'prevention and detection of crime... with far reaching consequences' (See also O'Brien, 2005). These changes, brought in from March 1981, were based on a report drawn up by Sir Patrick Walker, believed to then be second in command of MI5 in Northern Ireland who later served as MI5 Director between 1988 and 1992; 'the last Director General with a 
colonial background' [Andrew 2009, 561, Walker report, quoted in O'Brien 2005, appendix 1, 150, Walker 2009). The Walker Report established a centralised intelligence and agent handling system that built the primacy of intelligence-gathering and counterinsurgency operations into the DNA of policing practices.

There were three key changes. First, all RUC officers (notably in CID) were required to hand over details of any contacts, sources or networks of informers to Special Branch who were now solely in charge of handling any 'agent or source reporting on subversive organisations' (Walker Report, quoted in O'Brien 2005, appendix 1, 153, 156). Second, new guidelines were issued for the conduct of interviews that prioritised over all else gathering intelligence on insurgent organisations and Special Branch informer recruitment. Finally, all arrests planned by CID required prior clearance from Special Branch so the latter could 'ensure that no agents of either RUC or the Army are involved' (Walker Report, quoted in O'Brien 2005, appendix 1, 151). Any decision to charge an informer or agent had to be the result of 'a conscious decision by both Special Branch and CID in which the balance of advantage has been carefully weighed (my italics)'. This was a system that institutionalised intelligence gathering and informer recruitment in exchange for deferring arrest and imprisonment, and the prevention of the arrest of agents once recruited even if they had been involved in criminal acts and extensive wrongdoing. It was a calculated, bureaucratised conduit to systematic collusion as a means of conducting a counterinsurgency campaign. As Walker's role suggests, MI5 (which had taken an increasingly prominent lead in counterinsurgency policing and intelligence work in the North) was instrumental in designing these crucial changes in policing practice, implemented in secret rather than the result of legislation or any public policy process (Hillyard 2013, 2. See also Andrew 2009, 699-700)." The Walker Report may have 'given the lead role' in policing to RUC Special Branch but 'MI5, having devised the strategy, played a significant role behind the scenes. They pulled the strings'. An era when security policy in the North has often been characterised as defined by 'police primacy' witnessed not only the increased militarisation of the RUC but the primacy of counterinsurgency as the dominant paradigm of policing; a process that re-constituted the very nature of policing itself, and helped entrench a culture of systemic collusion. 


\section{'Leaks', Guns and Loyalist Violence}

\section{Providing Intelligence}

In the 1980s and early 1990s the security forces were far and away the most important source of intelligence for loyalists. Indeed the scope and scale of the 'leaking' of intelligence from the security forces to loyalist paramilitaries revealed in the de Silva report is astounding. For example, after dismissing any 'questionable' reports of 'leaks' de Silva $(2012,252)$ still found 270 separate instances of information being handed over to the UDA alone in less than a two-year period between 1987 and 1989. This included 'accurate and sensitive targeting information on republicans; information about the identity of informers; advance notice of arrests and operations; and, on occasion, weapons' (de Silva 2012, 251). Nearly half of the leaks involved information for targeting republicans (de Silva 2012, 254255).

This was known at the time by state authorities. Several MI5 reports throughout the mid to late 1980 s found that the vast majority of leaked information came from members of the RUC and the UDR (Security forces compendium of leaks 1989, quoted in de Silva 2012, 255). Intelligence on 'republican targets' had 'greatly increased' including 'the passing of montages or photographs' and the supply of weapons (Security force loose minute, quoted in de Silva 2012, 324). This often involved highly sensitive intelligence material provided by members of counterinsurgency units including senior UDR and RUC officers who 'may have been providing assistance to loyalist paramilitaries', particularly in terms of the procuring weapons (de Silva 2012, 257-259). Indeed, incredibly, that $85 \%$ of loyalist intelligence had originated from state files is likely an underestimation (Security Service, HAG to Director and Co-ordinator of Intelligence (DCI), 29 September 1989, quoted in De Silva 2012, 253-255). This was a widespread and endemic practice pivotal in developing the capacity for violence of loyalist organisations in this period, particularly where directed against republicans. ' have no doubt', noted de Silva $(2012,255,260)$, 'that most UDA targeting and attacks during the late 1980 s could be traced back to initial security force leaks' ensuring the UDA was 'in a position to mount an effective campaign'. State-sourced intelligence made possible the 
UDA's strategy of accelerated violence in this period and that was known to be the case by the intelligence agencies at the time.

Alongside RUC Special Branch at the heart of this collusive activity was the main intelligence unit of the British military operating in the North; the Force Research Unit (FRU). The primary means for the FRU to get sensitive intelligence material into loyalist hands was Brian Nelson (de Silva 2012, 253). A native of Belfast and former British soldier, Nelson was recruited by the FRU in the mid-1980s and soon after became Chief Intelligence Officer of the UDA, responsible for the collation, upkeep and dissemination of intelligence used in launching loyalist attacks. This allowed Nelson to act as a conduit for state intelligence and targeting information (including the names, addresses, photographs, layout of homes, transport and movement details of 'suspected' republicans) used in the rising number of loyalist assassinations in the late 1980s, including that of Pat Finucane (de Silva 2012, 118119).

\section{Providing Weapons}

The capacity of loyalists to significantly increase their violent campaign was also dependent on having access to a new arsenal of weapons. These came from several (often police or military) sources but a crucial part was played by a large cache imported from South Africa in December 1987 (Cusack \& McDonald 1997, 220-225; Taylor 2000, 188-195). There have been long term allegations that Nelson and his intelligence handlers were closely involved in arranging or facilitating this arms shipment (BIRW 1999; Panorama 1992; RFJ 2002, 1995; Sinn Fein 1997). While de Silva refutes these accusations his conclusion rests both on the questionable veracity and completeness of FRU and MI5 records (Madden 2015) and on the tenuous argument the arms shipment was the work of another loyalist organisation (Ulster Resistance) so that neither Nelson 'nor any other person in the UDA' was involved. In fact Ulster Resistance was a mass-based loyalist group founded in 1986 by the leadership of the DUP as a 'sort of clean-living paramilitary group' (Gregory Campbell DUP, quoted in Taylor $2000,187,190)$ through which 'loyalist politicians and business elements sought to harness the political potential of paramilitary muscle' in opposition to the Anglo-Irish Agreement 
(Aughey 1989, 75; Cochrane 1997, 161; McKitterick 1989, 170-172). It not only included former and serving members of the security forces in its ranks, but also leading loyalist paramilitary figures (including those within the UDA) in key roles. None more so than head of the UDA John McMichael, who had been central in developing the earlier arms links in South Africa that (even de Silva agrees) included a trip taken by Nelson funded by British intelligence. Indeed McMichael was a very close associate of Nelson and fostered his rise as UDA intelligence co-ordinator. McMichael himself, it has been suggested, was 'for many years a useful conduit for acting on British Intelligence targeting information' and may have been one among many informers and agents operating at senior levels in the UDA/UFF (Dillon 2003, 253-254).

Evidence from a later Ulster Resistance attempt to obtain weapons from South Africa also runs contrary to de Silva's conclusions. In 1989 three members of Ulster Resistance were arrested in Paris, along with arms dealer Douglas Bernhardt and a South African diplomat, attempting to exchange weapons for stolen sensitive military technology information muchsought by the embargoed South African Defence Force (Taylor 2000, 193-195; BBC 1989). The 'Paris Three' included Noel Little, a former UDR soldier and Head of Ulster Resistance (McKitterick 1991). According to a 'former senior employee with South Africa's Armscor' (Cobain 2012) while Little (who always suspected British Intelligence 'turned a blind eye' to the 1987 shipment) had long been the firm's key Ulster Resistance contact he was always 'told that the arrangements needed to be agreed by McMichael and by his intelligence officer - Brian Nelson. "Everything had to be run by the head of intelligence"". What is certain is that while some arms were recovered 'most of Ulster Resistance's share [of the South African weapons] and a good part of the UVF's remained intact' (Peter Taylor 2000, 192) and Ulster Resistance subsequently 'reached an agreement' with the UDA and UVF to share 'a portion of its [weapons] haul with them' (Holland and Phoenix 1996, 237). As Jeffrey Sluka $(2000,139)$ has argued, the result was a 'rearming of loyalists paramilitaries' and a 'major upsurge in sectarian killings in the first half of the 1990s'. In the six years prior to the arms shipment loyalists killed 71 people while in the six years from January 1988 to 1 September 1994, loyalists killed 229 people (Sluka 2000, 139; RFJ 1995, 3). By 1993, for the first time since the start of the troubles, loyalists were responsible for more conflict deaths than anyone else, including the IRA (McKitterick et al. 1999, 1476) 


\section{Providing Cover?}

According to Head of the FRU Gordon Kerr, Nelson only provided sufficient intelligence and resources to maintain his cover within the organisation and that he then passed on details of information provided to his FRU handlers. This is contradicted by the substantial evidence many loyalists strongly suspected (if not simply being aware) that Nelson was a state agent; not least given his evident open access to military and police files. It is a defence of Nelson's activities demolished by de Silva $(2012,119-121)$ who suspected Nelson's dissemination of material targeting 'republican personalities' was instigated by and done at the behest of the FRU. Nelson's handlers were aware state intelligence was distributed to UDA commanders allowing them to act 'independently' which 'greatly enhanced the UDA's potential for murder' while escaping arrest (de Silva 2012, 124). That Nelson also provided intelligence for targeting republicans to the 'more aggressive' UVF (who previously lacked such material) was anything but a strategy to 'save lives' and this was 'clearly understood' by Nelson's handlers (de Silva 2012, 128).

This was the exact reverse of Kerr's justification for Nelson's activities. Rather, the FRU and other branches of the security state had a growing interest in the increased military professionalisation' of loyalists (Crawford 2003, 44). Having agents and informers in crucial roles within armed non-state groups (loyalist and republican) allowed them to substantially influence, if not direct, their violent actions making them pivotal to the thrust of state counterinsurgency policy. Under FRU guidance and through the work of agents like Nelson loyalist paramilitary groups became a more deadly, sometimes more targeted force. Their killing capacity was increased, the ability to prevent attacks on 'republican personalities' reduced and republican deaths made more likely, as was the perpetrators escaping capture. Even as the number of blatantly sectarian victims grew, this looks like nothing so much as a systematic attempt to kill, demoralise and defeat the 'enemy' (the IRA and its supporters) at arm's length and beyond the bounds of the law. It takes a considerable effort not to see this as a strategy of targeted assassination by proxy. 


\section{Handling Agents, Informers and the Rule of Law}

The rules (or their lack) governing the handling of agents and informers is central to any discussion about collusion; not least in terms of what it was they were not only permitted, but directed to do. This was a major focus for de Silva who spends a considerable amount of time and energy looking at discussions among Cabinet members and with Northern Ireland Office (NIO) officials, senior legal figures and high-ranking members of the RUC, Army and intelligence services as to whether or not there should be guidelines for, essentially, what crimes agents and informers might 'necessarily' be allowed to commit and what crimes should be beyond the bounds of what was permitted. Certainly de Silva's report shows this issue regularly exercised the minds of senior members of the police and military, who consistently raised the matter at the highest political level. It is a big issue for de Silva because he wants to argue that the absence of such clear guidelines or a legal framework helped make possible collusion and the involvement of state agents in serious wrongdoing, up to and including murder. However, de Silva also wants to explain all this in a very particular way. That is because, despite being so regularly discussed within the highest echelons of the state, as we shall see, no meaningful or enforceable rules or limits on the actions of agents and informers were brought in throughout this period. Nothing, in that sense, was done. This raises the question why?

\section{A Void of Rule: the Legal Framework for Agent Handling}

During Nelson's trial Gordon Kerr complained about the 'armchair rules' for the handling of informers that supposedly prevented them from being involved in criminal activity (Dorrill 1993, 202). In reality there was virtually no regulation and little guidance on what both handlers and agents could or could not do. No statutory framework existed at all, only 'nonstatutory guidance and direction' characterised by a 'looseness of terminology... and judicial uncertainty' (DPP note 18 October 1990, quoted in de Silva 2012, 70). RUC guidelines predated the conflict and the RUC themselves admitted they could not be 'strictly adhered to' without undermining an 'effective intelligence network' (RUC commentary on the Home Office Guidelines on the Use of Informants, 11 February 1988, quoted in de Silva 2012, 71). 
For Army Intelligence the guiding principles in place in the late 1980s and early 1990s were those issued in July 1986 by the recently appointed Commander of Land Forces for Northern Ireland, Major General Tony Jeapes (de Silva 2012, 72). Jeapes (uniquely for someone in his new role) had previously been Commanding Officer of the SAS and been responsible for the development of its strategy in North in the early 1970s. He had earlier served in the SAS in Malaya and Dhofar the late 1950s and 1960s. Jeapes took up his senior role in the North at the same time as a new General Officer Commanding (GOC) was appointed, Lieutenant General Robert Pascoe (Urban 1992, 88, 112). Both, suggests Mark Urban, 'were open to the idea of using Special Forces for ambushes'.

An absolute prohibition on undertaking or sanctioning illegal acts seemed, on the face of it, to be central to Army guidance. The official military instructions for source control and handling' stated it was 'unlawful for any person to authorise an illegal act' (quoted in de Silva 2012, 72). That at least was the theory. Yet, as Gordon Kerr's comments illustrate, the practice was somewhat different and seems to have been widely understood as such within intelligence and political circles. This is crucial and points toward a vital, violently productive space between an ostensible public and official norm of adherence to the law and the everyday practice of intelligence and counterinsurgency operatives, working in the context of a non-public institutional norm, where the law was rendered indeterminate. Kerr's perspective suggests the theoretical condition of legal compliance could never be met, even while it had to be publicly stated. In addition, while those legal standards were only ever 'guidance' they lacked the potentially prohibitive force of a statutory basis.

Certainly there was no lack of awareness of the issue of agent handling at the highest levels of the state; far from it. De Silva $(2012,75-88)$ shows that substantive discussion of the matter was taking place between various state political, military, policing and civil administrative agencies (and at the highest level) from at least March 1987 and continued, without legislative resolution, throughout the early 1990s. Indeed he argues this was not a question that suddenly emerged in the late 1980s and concludes the absence of clear legal guidance for handling informers was likely an issue to have arisen throughout the conflict. Nor was it hidden from Government; 'it was manifestly not the case', argues de Silva, 'that agent-handlers were seeking to conceal the general nature of their activities from those in 
authority; on the contrary, they wanted the political leadership to provide a clear framework and direction'. It was then an issue:

Considered extensively at Cabinet level and Government Ministers were clearly aware that agents were being handled in Northern Ireland without reference to adequate guidelines because no such framework existed. Ministers nonetheless continued to place a high priority on pursuing an intelligence-led approach to the terrorist threat. The result of this was that agent handlers and their supervisors were being asked to perform a task... that, in some cases, could not be carried out in a way that was both effective and lawful (my italics] (de Silva 2012, 90).

In other words, from the outset, there was a distinct 'lack of political will' to introduce formal changes or resolve 'grey areas' involving 'the demands placed on the intelligence sector and its legal capacity to achieve its objectives'; a perspective shared by the NIO and senior legal advisers (Commentary on Home Office Guidelines on the Use of informants by ACC Monahan, 11 February 1988, quoted in de Silva 2012, 77; Loose minute, ACC Blair Wallace to Chief Constable, 27 June 1989, quoted in de Silva 2012, 80). Even when new agent handler guidelines were eventually drawn up in 1990 by the NIO and later adopted by military intelligence and MI5 they were viewed by the Solicitor General as 'unpromising territory for Ministerial approval' because they amounted to little more than a call not to get caught (Handwritten note, Solicitor General, 11 August, 1992, quoted in Da Silva 2012, 81). Despite having been adopted by the intelligence agencies a later review similarly found they could not be formally approved by Ministers 'for fear that that may involve them in allegations of conspiratorial criminality' (Minute, Security Service Legal Adviser, 25 March 1992, quoted in de Silva: 2012 83). A further internal review chaired by the NIO Permanent Secretary of State Sir John Chilcot (later Chair of the Iraq war Inquiry) did little but extend unresolved senior level discussions beyond the IRA and loyalist ceasefires of 1994.

\section{Informers, Collusion and Deniability}


In his report Desmond de Silva has a very specific interpretation to explain the absence of a regulatory framework for handling agents and the 'wilful and abject failure' to put legislation in place. In essence de Silva characterises these discussions as a concerted but ultimately doomed attempt to arrive at some consensus on implementing rules governing the criminal acts of agents. It is a reading of events that now extends into the more recently published Government post-de Silva 'lessons learnt' document. It is now, in other words, the official narrative of what took place (HM Government 2015). This line of argument rests on a built in a priori assumption de Silva adopts. It is 'self-evident' he asserts, 'that the implementation of such an inherently difficult task as penetrating terrorist groups with agents would require the development of a detailed legal and policy framework' (de Silva 2012 , 69). In other words, establishing clear and binding rules for the handling of agents would have been a 'good' thing, not only for moral, legal or rights-based reasons but also in operational terms; in order to better achieve the strategic counterinsurgency ends for which agents and informers were being used. Throughout, de Silva then assumes this shaped the viewpoint and thinking that informed Government decision-making. It is similarly taken to explain why the issue was raised by high-ranking members of the police and the army. That they were pressing for Government-sanctioned rules on agent-handling as, amongst other things, the best means of achieving their strategic ends. The absence of any agreement on putting any such rules in place until after the conflict is over therefore emerges in this perspective as an apparent matter of regret for all concerned; in other words as a failure of policy making.

Yet there is another, more critical way of viewing this evidence, which is to understand the absence of such guidelines not as a failure of policy but rather its purpose; the opening up of a space of legal obscurity and plausible deniability that facilitated counterinsurgency practice rather than hampering it. Not having clear laws and guidelines in place as to how informers and agents should be handled, and how they in turn should act, might rather be seen as the means to allow them to be handled and act in ways that were, to all intents and purposes, contrary to the rule of law but consistent with the end goal of counterinsurgency; the defeat of the IRA and the preservation of the state's order. An alternative assessment of what was taking place might rather understand the 'wilful failure' to put a regulatory framework in place to be (while certainly 'wilful') only a 'failure' in the immediate sense of 
not creating a legal basis for actions that were intended to facilitate the 'successful' achievement of this wider objective. Apart from anything else, if collusion is understood to include deliberately 'turning a blind eye' to wrongdoing, this in itself would constitute institutionalised collusion at the highest political level. De Silva (quoted in Ware 2012) might then have lent more weight to his own conclusion that the 'system [for agent handling] appears to have facilitated political deniability... rather than creating mechanisms for an appropriate level of political oversight'. That was not a failure, it was the point.

Indeed de Silva's report contains much evidence to support this alternative reading, including one telling comment from a former senior RUC officer recalling a remarkable meeting held with Margaret Thatcher and members of her cabinet in the late 1980s. When Thatcher asked what was needed to 'combat terrorism effectively' she was told by the RUC officer that 'he regarded as essential a sound legislative basis on which intelligence operations could be conducted lawfully' and that the management of agents and informers was made 'infinitely more difficult because they were operating in a grey area, and in the absence of a sound legal framework' (Anonymous Senior RUC Officer (R/15), quoted in de Silva 2012, 88). The recalled Government response is highly significant:

Essentially that the issue was too difficult to handle, and that SB [Special Branch] should continue as before. [R/15] said there was a reluctance to give official recognition to what SB was doing, the effect of which would be to authorise agents of the State to allow informants to take part in activities that could lead to the commission of terrorist offences. [R/15] said that the gist that he took from the Government's response was, in effect, 'carry on with what you are doing but don't tell us the details' [my italics]. This remained the attitude until around 2000 when the effect of the Human Rights Act 1998 (HRA) coming into force required the Regulation of Investigatory Powers Act 2000 (RIPA) (Minutes of a meeting with senior RUC officers, 25 July 2012, quoted in de Silva 2012, 89).

In other words, the lack of a statutory framework for the handling of informers was not understood by senior political figures as a difficulty so much as a means by which counterinsurgency actions and practices could take place that could otherwise not be 
legally, or politically, defended. There was an instrumental and strategic advantage in recognising but not formally acknowledging the modus operandi of Special Branch at the time. Nor was this an isolated incident. Rather, according to de Silva, it is 'strikingly consistent with the picture revealed by UK Government files'. Indeed, legislation would not be put into place until after the signing of the Good Friday Agreement (and the conflict essentially ended) in the form of the Regulation of Investigatory Powers Act 2000 (RIPA). In other words, after the war was essentially over. Despite protestations to the contrary, the 'grey spaces' did not inhibit the counterinsurgency use of informers and agents but rather facilitated the political deniability of 'exceptional' practice.

\section{Collusion, Culpability and the 'Ulsterisation of Blame'}

Senior military and police figures undoubtedly expressed concerns about the lack of a clear legal basis for their actions, although there is little evidence suggesting this was from a desire to prevent collusive practices, as de Silva assumes. Rather, much points to a fear (shared by senior members of the military, police and intelligence agencies) that operating in a 'grey area' of 'twilight legality' might leave them criminally accountable for their actions at some future point while their political masters sheltered behind official denial. For example, amid (ultimately failed) attempts to charge members of the RUC for conducting a shoot-to-kill policy in the wake of the Stalker Affair, senior RUC officers argued informer handler guidelines were regularly breached and left RUC officers open to possible prosecution (NIO record of meeting, 13 March 1987, quoted in de Silva 2012, 76-78; Jennings 1990,118). Indeed it is striking that the key issue raised throughout was not that such actions and practices should be stopped, but that guidelines and the law needed to be changed in order to protect the position (and prevent the prosecution) of agents and their handlers. In other words, to give legal sanction, and prevent potential legal culpability, for what was being done, rather than stopping the activities themselves. It was a position shared by other senior state officials. The problem, according to John Chilcot, was that 'existing law appears to leave agents, handlers and others involved in the intelligence process - including Ministers - unduly exposed' (Submission of John Chilcot to the Secretary of State, 14 July 1993, quoted in de Silva 2012, 86). Fears of later exposure to culpability 
echo what has more latterly been referred to as the Ulsterisation of blame' (Consultative Group on the Past 2009, 68. See also Lawther 2010, 2013; Lundy and McGovern 2008). Something of this view is again captured in the (seemingly embittered) words of the Gordon Kerr to the Stevens III inquiry in 2002:

I believe the wilful neglect in this matter lies with successive governments who despite calling for counter terrorist intelligence measures and reaping the political rewards of FRU's work in Northern Ireland have ignored Blelloch and Chilcot and have deliberately failed to address [my italics] the need for a more complete legal framework and more detailed guidelines (A/05, statement to Stevens III Investigation, 2002 quoted in de Silva 2012, 88).

Putting a 'clear framework' in place would have involved a declared, legally binding, official sanction of such practices. The 'lack of a political will' to introduce legislation is what helped generate a space of deniability that limited the chain of potential responsibility, absolved the Government of direct culpability and ensured the 'ulsterisation of blame' became a possibility.

\section{Counterinsurgency and the Liberal Ideology of Collusion}

States might reasonably cite a principle of self-defence as justification for utilising a range of means at their disposal (political, diplomatic, military), including intelligence-led operations and the use of agents and informers, when faced by violent political opposition or armed insurgency. Most (if not all) states have employed 'human intelligence' for such ends (Gill and Phythian 2012, Hewitt 2010). That said, within liberal democracies, any such practices are normally defended as continuing to conform to the norms and practices of the rule of law, even when the juridical order has been substantially re-shaped, or subverted, by 'emergency' measures. Of course, it is precisely the place and role of the rule of law in the use of agents and informers in Northern Ireland that is under scrutiny. The darkest, starkest problems in the relationship between the covert practices of the state and the juridical order emerge if such collusive intelligence work is seen to have been pivotal in conducting a 
state campaign of targeted assassination and extra-judicial killing (including the killing of 'non-combatants') by proxy.

How then might all this be understood and what does it tell us about the relationship between the practices of state violence, the exercise of power and the rule of law? A parallel case of counterinsurgency practice in the 'war on terror' may provide some useful insights. In a seminal critique of the rise of a 'torture culture' in post-9/11 America, Georgetown Professor of Law David Luban (2005) argues that the founding tenets of liberal democracies contain both the conditions for abhorrence toward the use of torture and the philosophical underpinnings for its justification. Indeed Luban (2005, 1430-1438) suggests liberalism's theoretical antagonism toward torture is even more fulsome than against state killing because it ranks the cruelty inherent in torture 'the first among vices' exemplifying the 'terrorizing' effect of the 'tyrannical political relationships liberalism hates most'. Despite this, the self-same 'liberal' ideas' that make torture so 'morally unacceptable... at a deeper level... can justify interrogational torture in the face of danger', at least for the purpose of intelligence gathering; the flawed logic of the so-called 'ticking bomb' scenario (Luban 2005, 1427. See also Brecher 2007; Jackson 2007, Luban 2014, 2013). That liberalism, broadly understood, insists upon limited governments that 'exercise their power only for instrumental and pragmatic purposes' makes possible viewing torture as 'civilised' when aimed at 'preventing future harms' (Luban 2005, 1436). Here torture becomes divorced from cruelty 'authorised and administered [as Luban puts it] by decent human beings who might abhor what circumstances force them to do' Justified on the pragmatic basis of preventing a supposed future 'greater evil' is what Luban $(2005,1439)$ terms the 'liberal ideology of torture'. This is the triumph of a doctrine of necessity and one directly analogous to that which underpinned institutionalised collusion.

In the context of an 'emergency' or belief of an impending 'catastrophe' a doctrine of apparent pragmatic necessity is what determines what becomes 'allowable' for liberal democracies, even to the extent of using forms of violence (such as torture) that apparently stand in absolute contradiction to the 'values' ostensibly being defended (such as the absolute prohibition of torture). Given the bureaucratic orders and institutional settings of state agencies there is in addition a tendency toward the corrosive normalisation of forms 
of otherwise impermissible violence. This is particularly so where the resort to secrecy to offset the rise of a public culture of ostensibly prohibited forms of state violence does not so much avoid the normalisation of such violence as merely 'layer on top of it the normalisation of state secrecy' (Luban 2005, 1446). Secrecy within state institutional orders and the cumulative experience of rules-breaching violence carried out by state agents similarly shifts the normative ground upon which they operate. The only thing likely to act as a bulwark against this road toward abuse, Luban tellingly concludes $(2005,1448)$ 'is a clear set of bright-line rules' inculcated 'with the intensity of religious indoctrination'. In their absence, as 'necessity' trumps all else, the limits of the permissible are seen to be porous, expansive and highly contingent on circumstance while rights-based criticisms are dismissed in turn as absolutist. Not least, perhaps, because adherence to 'values' may be of considerable less significance than the defence and promotion of interests.

Just such a doctrine of 'necessity' has also been evident throughout the history of British military counterinsurgency thinking, which has in turn been critical in framing British Government policy in its use of organised violence. (McGovern 2015). Much trumpeted during the decade of the 'war on terror', the idea that the tradition of British counterinsurgency has ever evidenced a singular commitment to the principle of 'minimum force' or a non-coercive 'hearts and minds' approach has more latterly been widely and thoroughly discredited (see for example Bennett 2012, 2009, Dixon 2009, Elkins 2005, Hughes 2009, Newsinger 2002). Rather, from its roots in the 'small wars' of Victorian imperialism, it is a tradition more concerned with calibrating the use of organised violence to achieve its required ends (Khalili 2012). It was a tone set by the man credited in the British Army's current field manual as the late nineteenth century founder of modern British counterinsurgency, General Sir Charles Callwell. Of solidly Ulster capital and Anglo-Irish landed stock, Callwell was one of a generation of unionist Anglo-Irish military officers who rose to prominence and influence in the pre-1914 period and during the years of the Home Rule crisis, partition and the creation of the Northern Irish state (McGovern 2015). Callwell advocated the use of what he termed 'moral force' in campaigns against 'impressionable savages and guerrillas'. By 'moral force' Callwell meant achieving desired strategic goals through a system of violence specifically designed to 'overawe and terrify' (Callwell 1906, 80). 
More latterly adherence to the rule of law has been proclaimed as the cornerstone of British counterinsurgency. Yet experience suggests such claims represent little more than a form of 'magical legalism' where expediency subverts norms and standards behind a mask of reshaped legality (Cohen 2001). Nowhere is this more clearly evident than in the work of General Frank Kitson $(1977,1971,1960)$. Long identified with the conflict in the North and the issue of collusion, not only because of his work on counterinsurgency theory but because he served in a senior role in the North in the early years of the conflict, Kitson was a public advocate of the use of what he termed 'pseudo' or 'counter-gangs'. He is credited with creating a covert British intelligence unit called the Military Reaction Force (forerunner to the FRU) in the early 1970s. Made up of plains-clothed members of the British army the MRF operated as a covert gang that carried out assassinations and direct attacks; some explicitly sectarian. As one unrepentant former member told a recent BBC Panorama documentary (2013) 'we [MRF] were not there to act like an army unit. We were there to act like a terror group'. There are allegations that such units worked in tandem with loyalist paramilitaries in carrying out some of the worst atrocities of the period, including the 1971 McGurk's bar bombing and the 1974 Dublin-Monaghan bombings (Cadwallader 2013, Cassels, Kemp, Pigou and Sawyer 2006, MacAirt 2012, Tiernan 2006). Only in 2015 the family of a victim of a 1973 loyalist killing has brought a civil case against Kitson personally and the Ministry of Defence for their part in fostering loyalist counter-gangs in that period (Bowcott 2015). iii

While Kitson $(1971,69)$ suggested that impartiality in the application of (even 'tough' new 'emergency') laws might be desirable, and in theory apply equally to state and military forces as well as others, he also suggested this was often 'unworkable' as part of a counterinsurgency campaign. Necessity, he therefore (somewhat infamously) argued, might dictate a different approach, that the 'law should be used as just another weapon in the government's arsenal, and in this case it becomes little more than a propaganda cover for the disposal of unwanted members of the public'. The key problem for the political system was therefore to create a juridical order that could at one and the same time protect state agents carrying out counterinsurgency operations that might normally be deemed illegal but which allowed state agents to do 'what was necessary' to preserve state interests. 
Yet the very idea of 'necessity' is itself a politically powerful mask and illusion; an enabling fiction. As Giorgio Agamben (2005) has argued, while often presented in objective terms 'necessity' is always a matter of subjective political judgement and decision; it is always a matter of 'necessary for what and necessary for whom'? Indeed, as Agamben goes on to suggest, even where an act is deemed 'necessary' to preserve the existing order this presumes in the first place there is agreement the existing order is worth preserving (Agamben 2005, 30). It is this political logic of necessity that is instrumentalised in the 'voluntary creation of a permanent state of emergency' (whether or not formally declared) (Agamben 2005, 3. See also McGovern 2011). It underpins the 'state of exception', the suspension of law and legal norms and the exercise of arbitrary decision that for Agamben has become the 'dominant paradigm of government in contemporary politics' in the era of the 'war on terror'. Rather than a paradigm of a 'hearts and minds' strategy to irregular warfare, this is the sense in which the British state's approach to counterinsurgency and public policy-making in Northern Ireland might be seen as a precursor to contemporary state practice, not least in terms of collusion. It is just such a 'no-man's land between public law and political fact' in which collusion took shape (Agamben 2005, 2). In the context of the 'emergency' the state faced in Northern Ireland, in its counterinsurgency campaign against insurgent Irish republicanism the actions of state agents who 'break the order to save it' would lie 'beyond the sphere of law' not least through the creation of a legal vacuum in the handling of agents and informers that 'suspended' legal norms and 'in-acted' the law (Agamben 2005, 46, 50).

\section{Conclusion}

As the US Senate report into post-9/11 US torture practice has recently amply confirmed, legal re-interpretations of torture were crucial in instituting a 'torture culture' as a means to wage the 'war on terror' (Amnesty International UK 2015). There are close parallels in the many shifts in law sanctioning violent state practices that took place during the Northern Ireland conflict. That is most obviously evident in the way the legal reframing of the British state's torture used against the 'hooded men' as 'cruel and degrading treatment' provided a 
'loophole exploited by US torture lawyers' (Luban 2005, 1458). But there are other parallels too, more closely concerned with the story of collusion. From the early 1980s onwards, the neutering of the inquest system (CAJ 1992), the ever looser interpretation of 'reasonable force' adopted in 'shoot-to-kill' cases (Jennings 1990, Murray 1990, Ní Aoláin 2000) and the emerging primacy of agent and informer-led policing strategies are examples of organised policy practices that helped to shape and foster what we might think of as a 'collusion culture' as the means of prosecuting a counterinsurgency war.

It is also in that light that we might view the creation of a lacuna in the law by not setting clear legal limits to the actions of agents and their handlers, and the evidence of the wholesale elite-led obstruction of the truth about collusion coming out. It is because both are indicative of the wider bureaucratic means employed to permit collusion as a counterinsurgency practice to continue into the future. Or, following Luban (2005), what we might see as evidence of a 'liberal ideology of collusion' and the bureaucratic normalisation or 'civilising' of a 'culture of collusion'. This is not a situation that came about through oversight or an absence of thought. Rather it involved the public projection of a myth of legality that could permit the conduct of counterinsurgency operations regarded as 'necessary' to meet the end goal of defeating (or at least successfully containing) the state's prime 'enemy', the IRA. At one level, the dilemma facing the state was to either stop what was happening or, to all intents and purposes, formally recognise it was involved a colonial war and the instigation, planning and practice of premeditated, 'unlawful' killing. Yet it was precisely the suggestion that a colonial condition existed that the ideological struggle against Irish republicanism was specifically designed to negate. In the context of a counterinsurgency campaign that had to be presented (as far as the state was concerned) as operating within the confines of the 'normal' juridical order such a step was politically and ideologically unpalatable. It would have required a formal acknowledgement of the 'state of exception' and it was such explicit official recognition that would have been contrary to the British juridical tradition, and the British way of counterinsurgency (Agamben 2005, 10). On the other hand, creating ungoverned spaces in the context of an 'emergency' in which the actions of state military, policing and intelligence forces in their handling and directing of agents and informers could be denied, or the law rendered essentially inoperative, was very much in line with those traditions. This was an approach to counterinsurgency characterised 
not by a commitment to 'minimal force' but an increasingly normalised ends-driven, instrumental pragmatic logic, that through our own recent past and up to the present, has been able to rationalise and authorise the use of extra-judicial violence that is neither rules bound, rights framed or constrained by law when found to be 'necessary'. That is what we might think of as the liberal ideology of collusion.

\section{References}

Agamben, Giorgio. 2005. State of Exception. Chicago IL: University of Chicago Press. Amnesty International UK. 2015. 'Paper trail: From Northern Ireland's Hooded Men to CIA's global torture'. Amnesty International UK Blog: Belfast and Beyond. url: http://www.amnesty.org.uk/blogs/belfast-and-beyond/paper-trail-northernireland\%E2\%80\%99s-hooded-men-cia\%E2\%80\%99s-global-torture.

Andrew, Christopher. 2009. The Defence of the Realm: The Authorised History of MI5. Harmondsworth: Penguin.

Aughey, A. 1989. Under Siege: Ulster Unionism and the Anglo-Irish Agreement. Belfast: Blackstaff Press

Bamford, Bradley C. 2005. 'The role and effectiveness of intelligence in Northern Ireland'. Intelligence and National Security, 20, 4, 581-607.

BBC. 2013. 'Britain's secret terror force', Panorama, first aired 21 November.

BBC. 1992. 'The dirty war', Panorama, first aired 8 June.

BBC. 1989. 'The South African connection: guns for arms', Spotlight, first aired 27 April.

Bennett, Huw. 2012. Fighting the Mau Mau: The British Army and Counter-Insurgency in the Kenya Emergency. Cambridge: Cambridge University Press.

Bennett, Huw. 2009. "'A very salutary effect": the counter-insurgency strategy in the early Malayan emergency', Journal of Strategic Studies, 32, 3, 415-444. doi:

$10.1080 / 01402390902928248$.

Bew, Paul and Henry Patterson. 1985. The British State and the Ulster Crisis. London: Verso. Bourne, Jenny. 2001. 'The life and times of institutional racism'. Race and Class, 43, 2, 7-22. 
Bowcott, Owen. 'Former general sued over death of Catholic minibus driver during troubles', Guardian, 27 April. url: www.theguardian.com/uk-news/2015/apr/27/northernireland-general-sued-death-catholic-troubles-heenan-kitson.

Brecher, Bob. 2007. Torture and the Ticking Bomb. Oxford: Blackwell.

British-Irish Rights Watch. 1999. Deadly Intelligence: State Involvement in Loyalist Murder in Northern Ireland. London: BIRW

Cadwallader, Anne. 2013. Lethal Allies: British Collusion in Ireland. Cork: Mercier Press. Callwell, Charles E. 1906. Small Wars: their Principle and Practice. 3rd ed. London: University of Nebraska Press.

Campbell, Colm and Ita Connolly. 2003. 'A model for the "war against terrorism": military intervention in Northern Ireland after the Falls curfew'. Journal of Law and Society, 30, 3, 341-375.

Cassels, Douglass, Susie Kemp, Piers Pigou and Stephen Sawyer. 2006. Report of the Independent International Panel on Alleged Collusion in Northern Ireland. Notre Dame, IN: Centre for Civil and Human Rights, Notre Dame Law School. Cobain, Ian. 2012. 'Northern Ireland loyalist shootings: one night of carnage, 18 years of silence', The Guardian, 15 October. url: http://www.theguardian.com/uk/2012/oct/15/northern-ireland-loyalist-shootingsloughinisland.

Cochrane, F. 1997 Unionist Politics and the Politics of Unionism sine the Anglo-Irish Agreement. Cork: Cork University Press.

Cohen, Stan. 2001. States of Denial: Knowing about Atrocities and Suffering. London: Polity Press.

Committee on the Administration of Justice. 1992. Inquests and Disputed Killings in Northern Ireland. Belfast: CAJ.

Consultative Group on the Past. 2009. Report of the Consultative Group on the Past. London: HMSO. url: http://cain.ulst.ac.uk/victims/docs/consultative_group/cgp_230109_report.pdf. Cory, Peter. 2004. Cory Collusion Inquiry Report: Patrick Finucane. London: HMSO.

Crawford, Colin. 2003. Inside the UDA: Volunteers and Violence. London: Pluto Press. Cusack, J. and McDonald, H. 1997. UVF. Dublin: Poolbeg Press (2nd edition).

De Silva, Desmond. 2012. The Report of the Patrick Finucane Review: Volumes I and II. London: HMSO. 
Dillon, M. 2003. The Trigger Men. Edinburgh: Mainstream Publishing

Cunningham, Michael. 2001. British Government Policy in Northern Ireland, 1969-2000.

Manchester: Manchester University Press.

Dixon, Paul. 2009. "'Hearts and minds"? British counter-insurgency from Malaya to Iraq', Journal of Strategic Studies, 32, 3, 353-381. doi: 10.1080/01402390902928172.

Dorril, Stephen. 1993. The Silent Conspiracy: Inside the Intelligence Services in the 1990s.

London: Heinemann.

Elkins, Caroline. 2005. Britain's Gulag: The Brutal End of Empire in Kenya. London: Random House.

Farrell, Michael. 1983. Arming the Protestants: The Formation of the Ulster Special Constabulary and the Royal Ulster Constabulary, 1920-27, London: Pluto Press.

Gill, Peter and Mark Phythian. 2012. Intelligence in an Insecure World. Cambridge: Polity Press.

Guelke, Adrian. 2007. 'The Northern Ireland peace process and the "war against terrorism": conflicting conceptions'. Government and Opposition, 42, 3, 272-291. doi: 10.1111/j.14777053.2007.00224.x.

Hearty, Kevin. 2014. "The political and military value of the "set-piece" killing tactic in east Tyrone 1983-1992'. State Crime, 3, 1, 50-72.

Hewitt, Steve. 2010. Snitch! A History of the Modern Intelligence Informer. London: Continuum.

Hillyard, Paddy. 2013. 'Perfidious Albion: Collusion and cover-up in Northern Ireland'. Statewatch, 22, 4, 1-14. url: http://www.statewatch.org/analyses/no-221-perfidiousalbion.pdf.

HM Government. 2015. Lessons Learnt by Government Departments from Sir Desmond de Silva's of the Patrick Finucane Review: A Report by the Cabinet Secretary, the Secretary of State for Defence and the Secretary of State for Northern Ireland, 16 January. url: https://www.gov.uk/government/publications/sir-desmond-de-silvas-report-of-thepatrick-finucane-review-lessons-learnt-report.

Holland, J. and Phoenix, S. 1996. Phoenix: Policing the Shadows. London: Hodder \& Stoughton. 
Hughes, Matthew. 2009. 'The banality of brutality: British armed forces and the repression of the Arab Revolt in Palestine', English Historical Review, CXXIV, 507, 313-354. doi:

10.1093/ehr/cep002.

Jackson, Richard. 2007. 'Language, policy and the construction of a torture culture in the war on terrorism', Review of International Studies, 33, 3, 353-371. doi:

\section{$10.1017 / S 0260210507007553$}

Jennings, Anthony. 1990. 'Shoot to Kill: The Final Courts of Justice'. In Justice under Fire: The Abuse of Civil Liberties in Northern Ireland, edited by Anthony Jennings, 104-130. London: Pluto Press.

Khalili, Laleh. 2013. Tim in the Shadows: Confinement in Counterinsurgency. Stanford CA: Stanford University Press.

Kirk-Smith, Michael and James Dingley. 2009. 'Countering terrorism in Northern Ireland: the role of intelligence'. Small Wars and Insurgencies. 20, 3-4, 551-573. doi:

10.1080/09592310903027132.

Kitson, Frank. 1977. Bunch of Five. London: Faber and Faber.

Kitson, Frank. 1971. Low Intensity Operations: Subversion, Insurgency and Peacekeeping. London: Faber and Faber.

Kitson, Frank. 1960. Gangs and Counter-Gangs. London: Barrie and Rockliff. Larkin, Paul. 2004. A Very British Jihad@ Collusion, Conspiracy and Cover-up in Northern Ireland. Belfast: Beyond the Pale Publications.

Lawther, Cheryl. 2013. 'Denial, silence and the politics of the past: unpicking the opposition to truth recovery in Northern Ireland'. International Journal of Transitional Justice, 7, 1, 157177. doi: $10.1093 / \mathrm{ijtj} / \mathrm{ijs} 029$.

Lawther, Cheryl. 2010. 'Securing the past: policing and the contest over truth in Northern Ireland'. British Journal of Criminology, 50, 3, 455-473.

Luban, David. 2014. Torture, Power and Law. Cambridge: Cambridge University Press. Luban, David. 2013. 'Military necessity and the cultures of military law'. Leiden Journal of International Law, 26, 2, 315-349. doi: 10.1017/S092215651300006X

Luban, David. 2005. 'Liberalism, torture and the ticking bomb'. Virginia Law Review, 91, $1425-1461$. 
Lundy, Patricia and Mark McGovern. 2008. 'A Trojan horse: unionism, trust and truth-telling in Northern Ireland'. International Journal of Transitional Justice, 2, 1, 42-62. doi:

10.1093/ijtj/ijm029

MacAirt, Ciarán. 2012. The McGurk's Bar Bombing: Collusion, Cover-up and a Campaign for Truth. London: Frontline Noir.

Madden, Peter. 2015. Public Talk, Collusion from Downing Street to Fortwilliam Drive: Pat Finucane Anniversary Talk, 12 February.

McDonald, Henry and Owen Bowcott. 2012. 'Pat Finucane report: David Cameron apologises over killing'. The Guardian, 12 December. url:

http://www.theguardian.com/uk/2012/dec/12/pat-finucane-report-david-cameronapologises.

McGovern, Mark. 2015. 'State violence and the colonial roots of collusion in Northern Ireland', Race and Class, 57, 2, 3-23. doi: 10.1177/0306396815595200.

McGovern, Mark. 2013. 'Inquiring into collusion? Collusion, the state and the management of truth recovery', State Crime, 2, 1, 4-29.

McGovern, Mark. 2011. 'The dilemma of democracy: Collusion and the state of exception', Studies in Social Justice, 5, 2, 213-230.

McKitterick, David, Kelters, Seamus, Feeney, Brian and Thornton, Chris. 1999. Lost Lives: The Stories of the Men, Women and Children who died as a Result of the Northern Ireland Troubles. Edinburgh: Mainstream Publishing.

McKitterick, David. 1994. 'IRA ceasefire: Unhappy Unionists left outflanked'. The Independent, 1 September. url: http://www.independent.co.uk/news/uk/ira-ceasefireunhappy-unionists-left-feeling-outflanked-fear-and-loathing-among-loyalists-run-deeperthan-suspicion-of-betrayal-1445925.html.

McKitterick, D. (1989) Despatches from Belfast. Belfast: Blackstaff Press.

McKitterick, David. 1991. 'Arms from Africa fuel paramilitary terror in Northern Ireland', The Independent, 29 October.

Moran, Jon. 2010. 'Evaluating Special Branch and the use of informant intelligence in Northern Ireland.' Intelligence and National Security. 25, 1, 1-23. doi:

10.1080/02684521003588070.

Murray, Raymond. 1990. The SAS in Ireland. Cork: Mercier Press. 
Newsinger, John. 2002. British Counterinsurgency: From Palestine to Northern Ireland. Basingstoke: Palgrave.

Ní Aoláin, Fionnuala. 2000. The Politics of Force: Conflict Management and State Violence in Northern Ireland. Belfast: Blackstaff Press.

O'Brien, Justin. 2005. Killing Finucane: Murder in Defence of the Realm. Dublin: Gill \& Macmillan.

Ó Dochartaigh, Niall. 2011. "'Everyone trying", the IRA ceasefire, 1975: a missed opportunity for peace?' Field Day Review, 7, 51-60.

O'Dowd, Liam, Bill Rolston and Mike Tomlinson. 1982. 'From Labour to the Tories: the ideology of containment in Northern Ireland'. Capital and Class, 6, 3, 72-90. doi: 10.1177/030981688201600109.

Pat Finucane Centre. 2014. The History of the UDR: The Secret Files Revealed. Derry: Pat Finucane Centre.

Relatives for Justice. 2012. Loughinisland Massacre: Collusion, Cover-up. Belfast: RFJ. Relatives for Justice. 2012a. Sean Graham Bookmakers Atrocity: Wednesday 5 February 1992. Belfast: RFJ.

Relatives for Justice. 2002. Collusion. Belfast: RFJ.

Relatives for Justice. 1995. Collusion 1990-1994: Loyalist Paramilitary Murders in North of Ireland. Belfast: RFJ.

Rolston, B. 2006. "Pro-State Paramilitaries, Truth and Transition in Northern Ireland." Human Rights Quarterly 28 (3): 652-675

Rolston, Bill. 1991. 'Containment and it's failure: the British state and the control of conflict in Northern Ireland'. In Western State Terrorism, edited by Alexander George, 155-179. London: Polity Press.

Sinn Fein. 1997. An Appalling Vista: Collusion, British Military Intelligence and Brian Nelson. Dublin: Sinn Fein.

Sivanandan, A. 2008. Catching History on the Wing: Race, Culture and Globalisation. London: Pluto Press.

Sluka, Jeffrey A. 2000. "'For God and Ulster': the culture of terror and loyalist death squads in Northern Ireland". In Death Squad: The Anthropology of State Terror, edited by Jeffrey A. Sluka, 127-157. Philadelphia PA: University of Pennsylvania Press. 
Smith, William Beattie. 2011. The British State and the Northern Ireland Crisis, 1969-73:

From Violence to Power-Sharing. Washington DC: United States Institute of Peace.

Stevens, John. 2003. Stevens Enquiry 3: Overviews and Recommendations, 17 April. url:

http://www.madden-finucane.com/patfinucane/archive/pat_finucane/2003-04-

17_stevens_report.pdf.

Taylor, Peter. 2000. Loyalists. London: Bloomsbury.

Tiernan, Joe. The Dublin and Monaghan Bombings. Dublin: Tiernan.

Urban, Mark. 1992. Big Boy's Rules: The Secret Struggle against the IRA. London: Faber and Faber.

Walker, Patrick. 2009. Towards Independence in Africa: A District Officer in Uganda at the End of Empire. London: The Radcliffe Press.

Walsh, Dermot P.J. 2000. Bloody Sunday and the Rule of Law in Northern Ireland. Dublin: Gill and Macmillan.

Ware, John (2012) 'De Silva Report on Finucane case turns spotlight on MI5', BBC News, 13 December. url: http://www.bbc.co.uk/news/uk-northern-ireland-20708070.

\section{Endnotes}

\footnotetext{
i This study focusses on the role of agents and informers in loyalist paramilitary groups and does not deal with the important story of those operating within the IRA and other republican organisations.

ii The existence of the Walker Report was only revealed by a BBC Northern Ireland Insight programme in 2001. See BBC 2001, O’Brien 2005, 6.

iii Eugene 'Paddy' Heenan was killed when members of the UDA threw a grenade into the minibus he was driving containing fourteen Catholic building workers (many of whom were badly injured) on their way to the construction site of a new Catholic school in east Belfast, 1 February 1973. The loyalist gang involved was led by Albert 'Ginger' Baker, who later alleged he was working with and for the MRF.
} 